959 Pis 595 bie

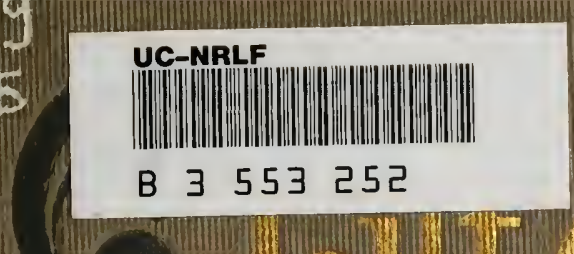

(p)

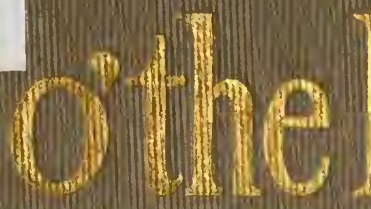

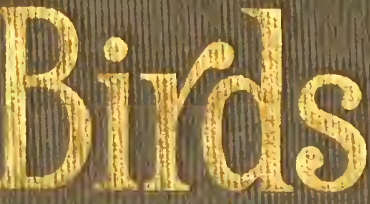
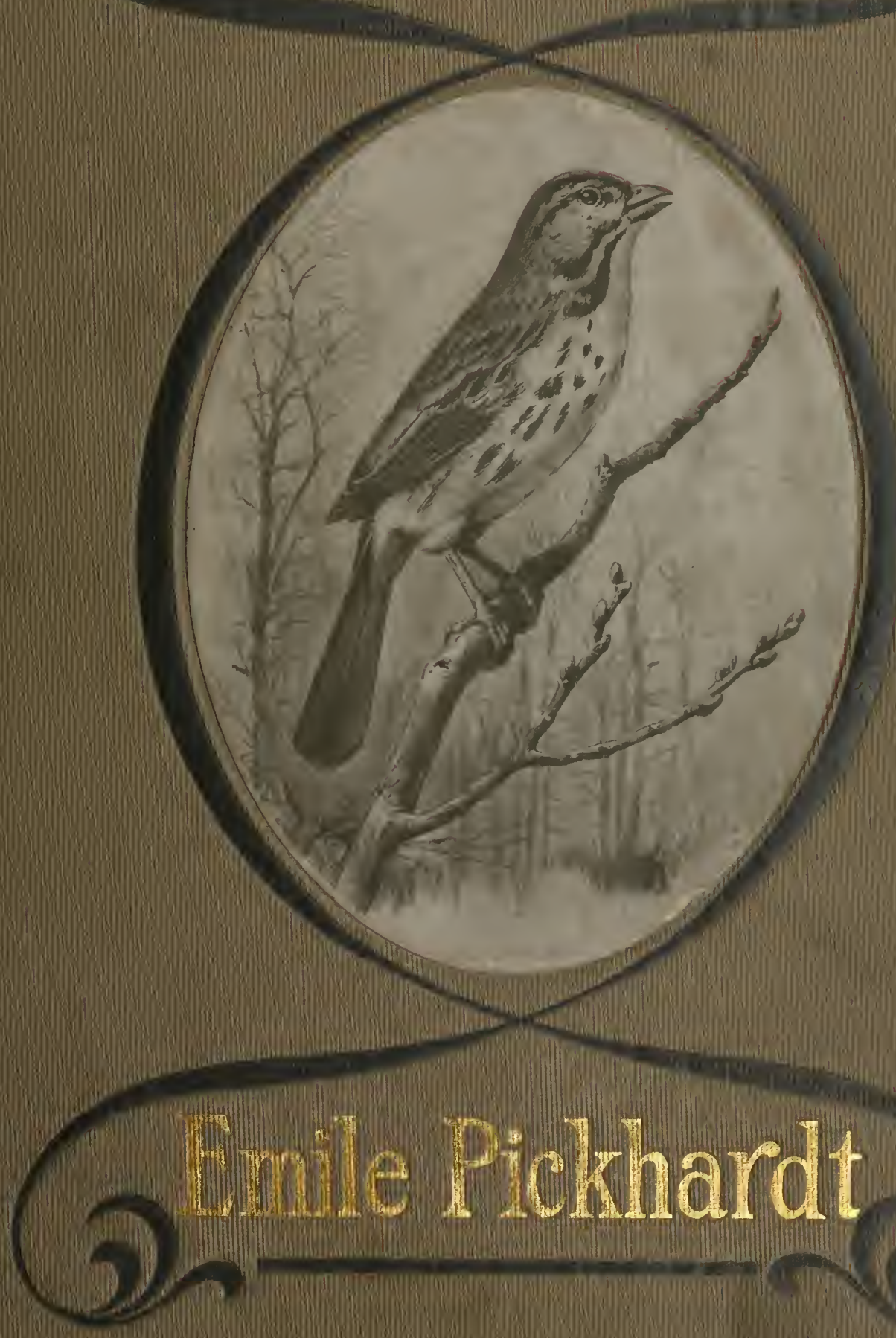


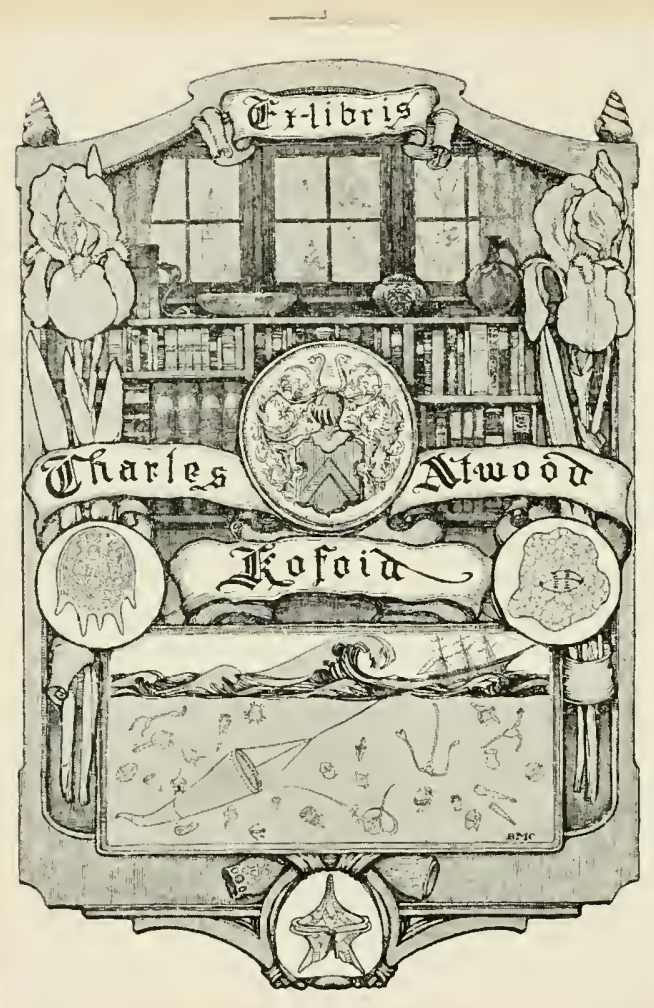



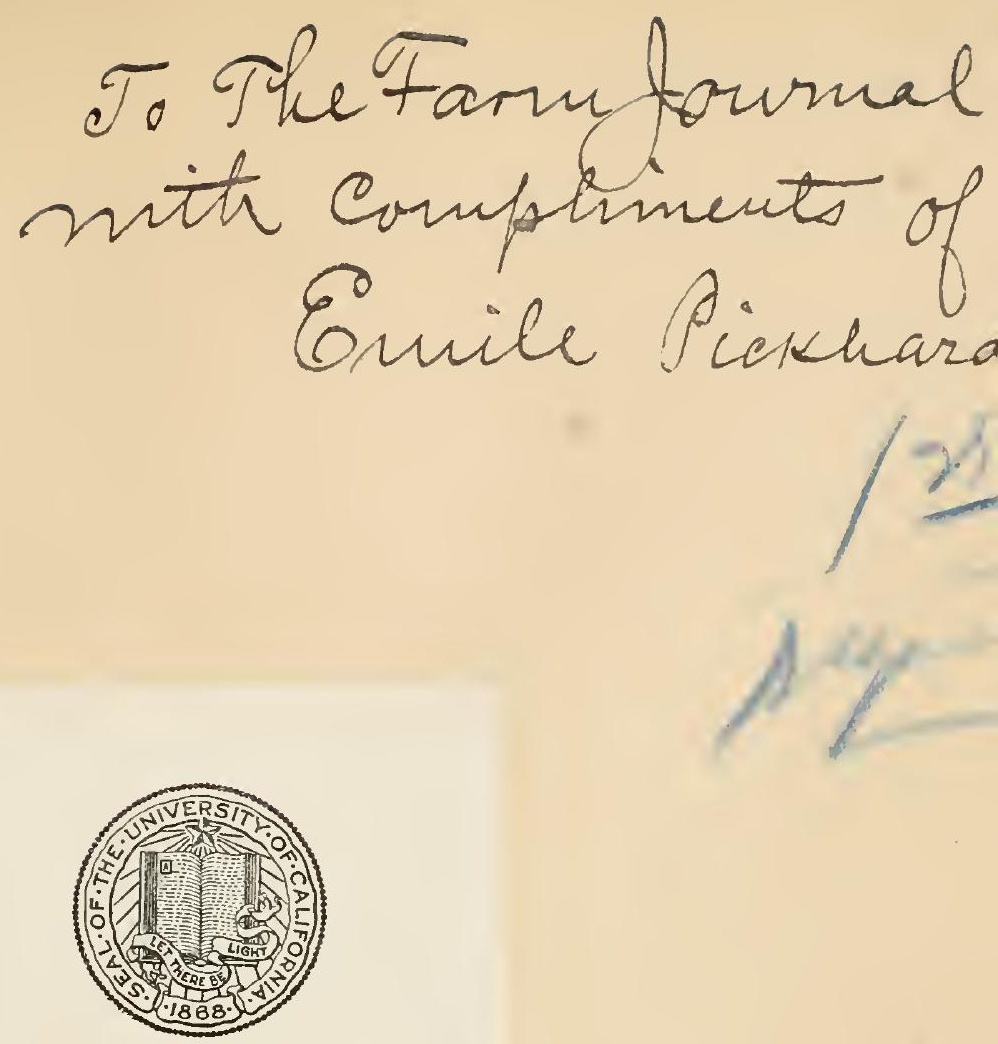

THE LIBRARY OF

THE UNIVERSITY OF CALIFORNIA

PRESENTED BY

PROF. CHARLES A. KOFOID AND

MRS. PRUDENCE W. KOFOID 








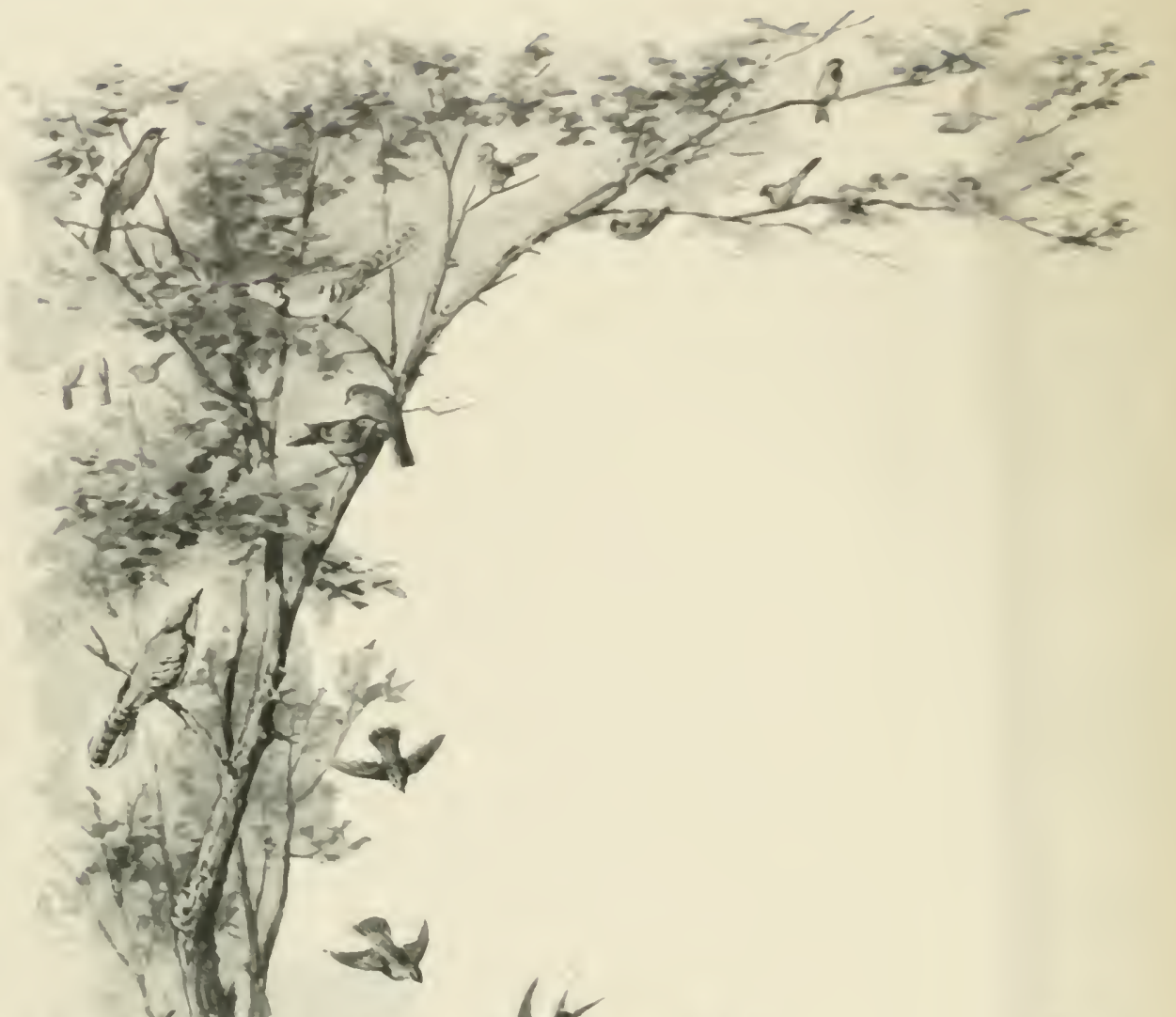

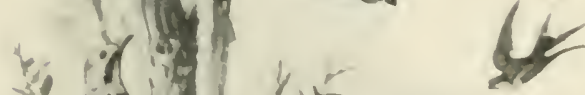

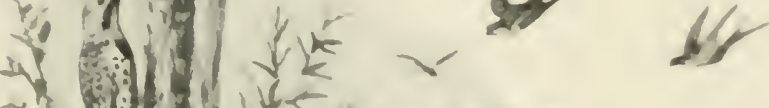

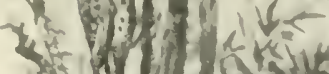

Sh

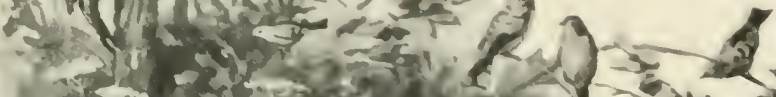

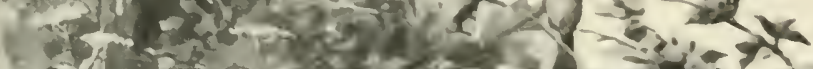

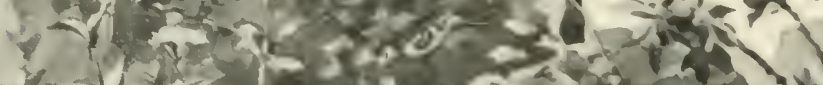

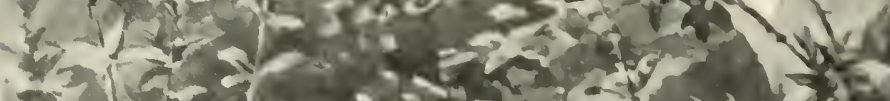

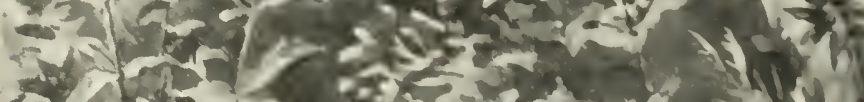

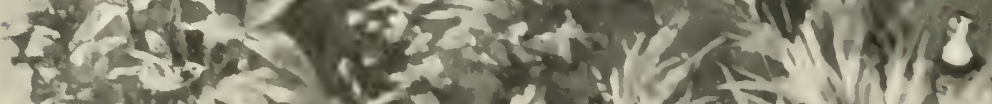

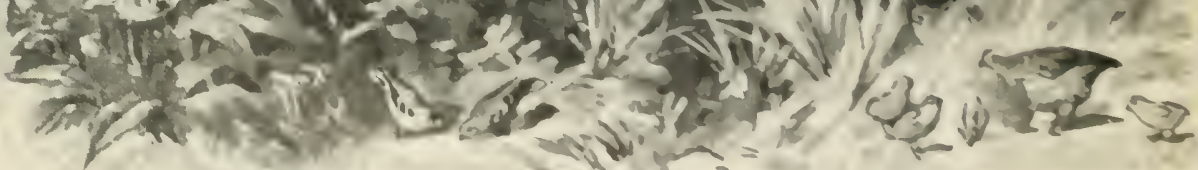

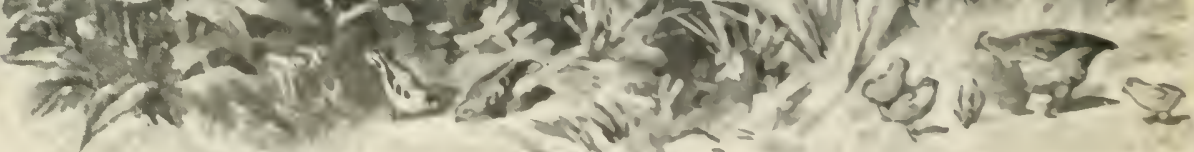




\section{Q THE BIRLS}

II

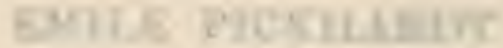

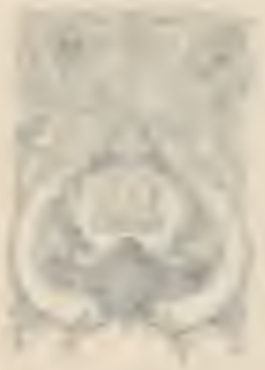

$7 \times$

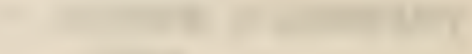




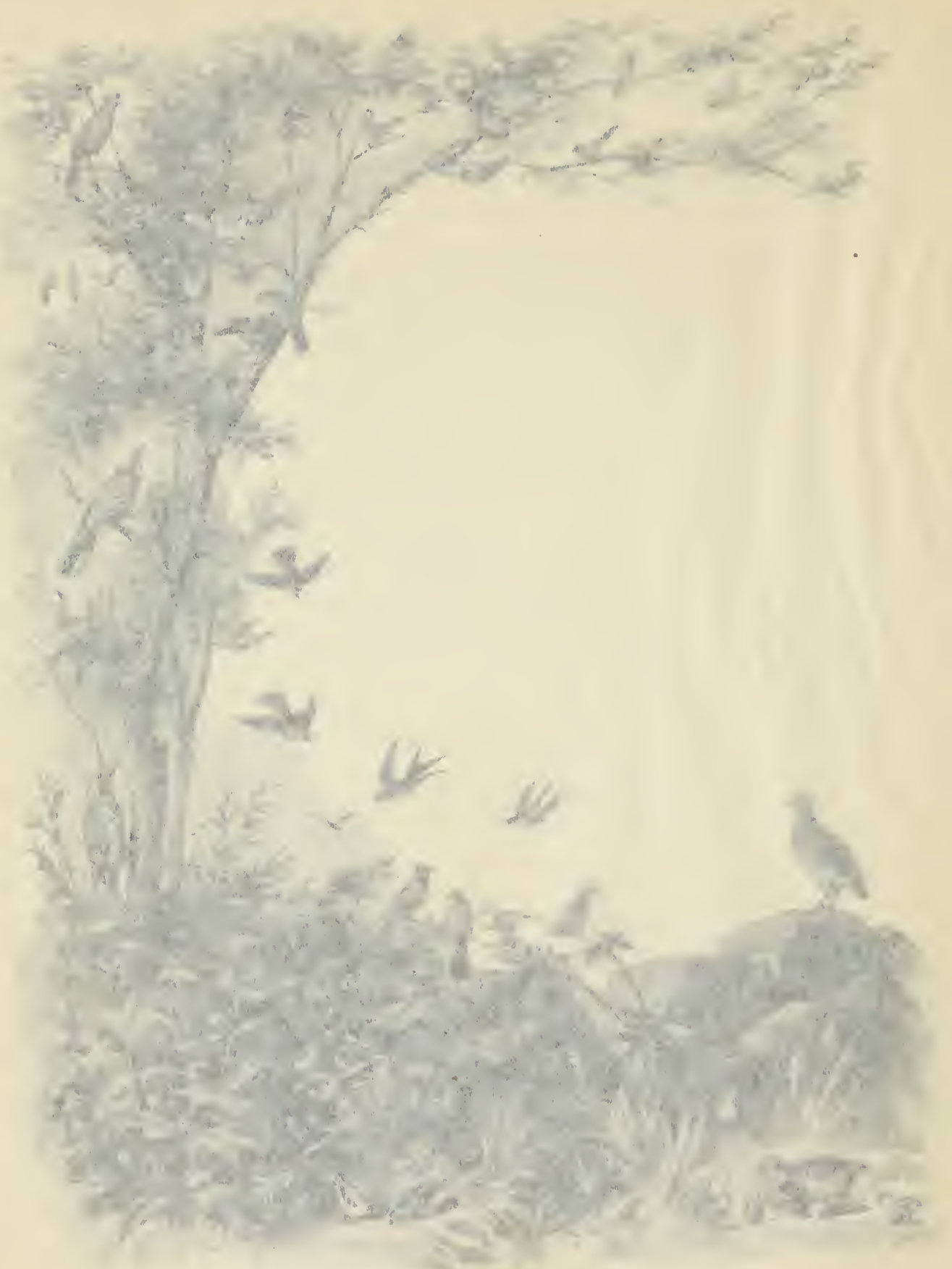




\section{LILT O' THE BIRDS}

BY

EMILE PICKHARDT

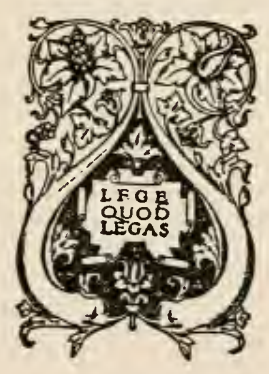

BOSTON

SHERMAN, FRENCH \& COMPANY

1912 
Copyright, 1912

Sherman, Frexch \&o Compant 


\section{CONTEN'TS}

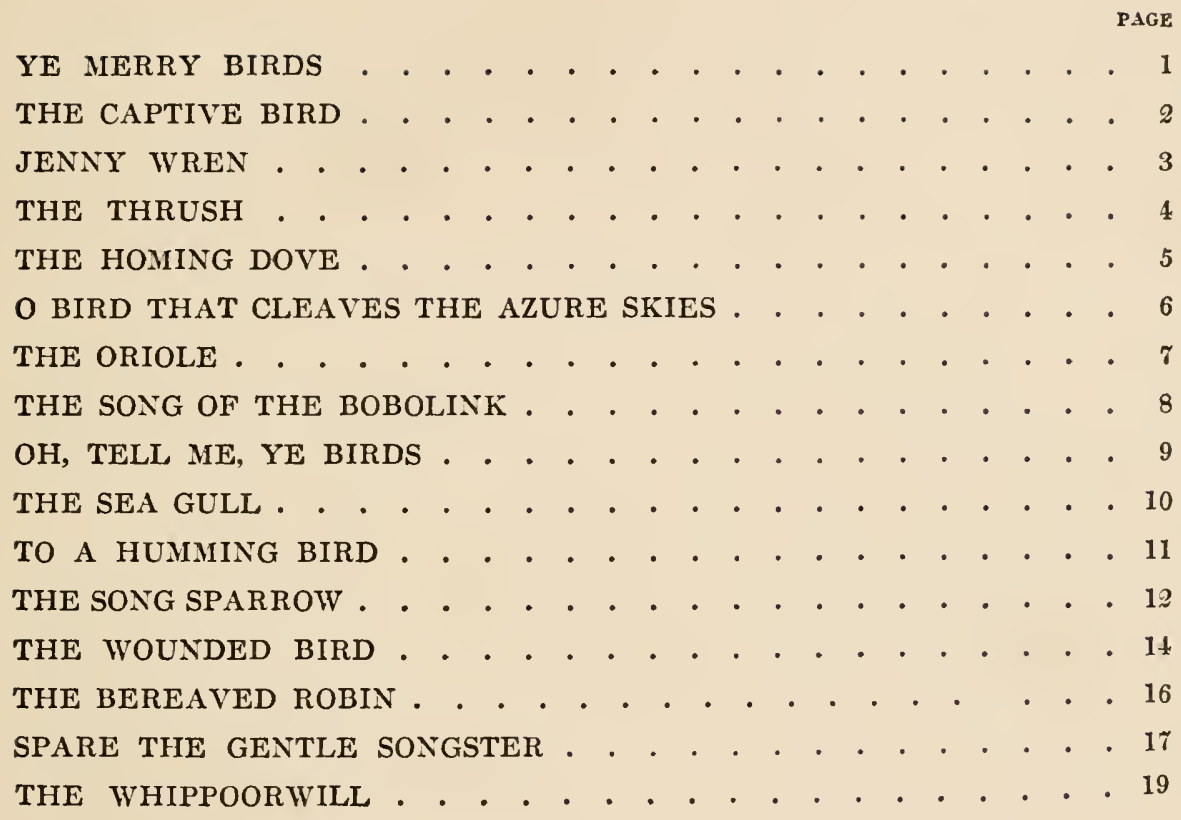





\section{ILLUSTRATIONS}

FRONTISPIECE

Facing page

THE THRUSH . . . . . . . . . . . . . . . . . . 4

THE ORIOLE . . . . . . . . . . . . . . . . . . . . . 7

THE HUMMING BIRD . . . . . . . . . . . . . . . . . 11

THE SONG SPARROW . . . . . . . . . . . . . . . 12

THE BEREAVED ROBIN . . . . . . . . . . . . . . 16 



\section{YE MERR I BIRDS}

$\mathrm{OH}$, where shall tongue or pen find words To sing your praise, ye merry birds;

Your pretty forms, your gentle eyes,

Your graceful flight athwart the skies;

Your plumage soft of colors rare,

Your joy songs pulsing everywhere?

$\mathrm{Nay}$, words of mine impotent seem

To fitly clothe the fertile theme.

Ah, what a cheerless world 'twould be Without your song and flight so free;

Nigh half the charm would disappear

Of springtime joys, were you not here

A sense of buoyancy to bring

And thoughts of hearen, when ye sing:

E'en summer's glow and autumn's hue

Were dulled and dreary without you.

And so I fain your charms would tell;

Nor could I fail to sing them well,

Befittingly to roice your praise,

Could I but cateh your thrilling lays;

Could my poor muse but with you rise

In flight amid the lambent skies-

Oh, surely then, I'd find the words

To sing of you, O merry birds. 


\section{THE CAPTIVE BIRD}

O HAPLEss captive, held by prison bars, From all of joy and hope in life apart,

Once of the free and joyous woodland throng

That fills the fragrant air with vibrant song

From palest dawn till waking of the stars,

Dost thou still hold the image in thine heart

Of all those lovely scenes-the budding flower, In verdant meadow, where the zephyr swayed

The crimson clover to the wand'ring bee;

The glory of the bloom-crowned apple tree Where, hid from ruthless gaze in April hour,

To thy dear mate thy trysting vows were made?

Oh, tell me, captive with the mournful lay,

That well might touch the coldest heart to hear,

Doth memory's torment follow also thee?

Is that the secret of the dews I see

Upon thine eyes, that gaze so far away,

As if through walls of granite thou could'st peer?

Does still the image of thy gentle mate

Dwell in thy soul, with whom thou e'er didst fly

With each recurring spring to seek again

That lovèd spot where hope and joy did reign, Where near the downy nest thou didst await

With swelling song thy tender brood's first cry?

Ah, surely, this the secret font must be

Of that supernal pathos in thy song,

That floods my soul with wistful memories

Of lost delights, as floods the twilight breeze

The swaying pines with mournful harmony,

Whose sobbing chords to spirit choirs belong. 


\section{JENNY WREN}

O Jenny Wren, O Jenny Wren, So you have found a resting place To raise your little brood again, Within the dear old nesting place:

There 'neath the eaves, where drooping leaves

Of willow branches swinging low, Soft lullabys 'neath lambent skies

Are ever sweetly singing low.

O Jenny Wren, O Jenny Wren, I love your bright and funny ways;

I love to see you building when The world is glad with sunny days.

You primp and preen with knowing mien When Johnny Wren comes flying near;

A true coquette as e'er I've met, You are, without half trying, dear.

O Jenny Wren, O Jenny Wren, With all your pert and canny ways,

I'm glad to welcome you again, And hope you'll bide here many days;

A brood to rear of birdlings, dear, On whom you'll lavish dearest love, And by and by teach them to fly, And cleave the sunny skies above. 


\section{THE THRUSH}

WHen at the day-god's light caress, Aurora, stirred from sweet repose, Still thralled in drowsy listlessness, Doth trembling eyelids half unclose;

Or when the garish day declines

And all the world seeks balmy rest, When twilight softens forms and lines, Then sings the wood-thrush at his best.

Alone, in some sequestered bow'r,

Where leafy arches cast their shade And cool, at mid-day's torrid hour, The brooklet winding through the glade;

Where human discord, all unknown, Ne'er breaks of sacred hush the spell;

There, in his cloister, all alone, In shy seclusion doth he dwell.

Now pause; approach not all too near

His favored haunt with careless tread,

So you a chorister would hear

Whose rhapsodies might wake the dead.

Untutored, he has caught the art Alone, where nature's spirit broods, Of giving voice to nature's heart And weaving chorals from her moods.

No suitor bold for men's applause, Unconscious of his powers, he

From nature inspiration draws

And fills her halls with harmony.

In woodland haunts, inviolate

By mortals' sordid clamorings,

To his Creator and his mate

He brings his choicest offerings. 


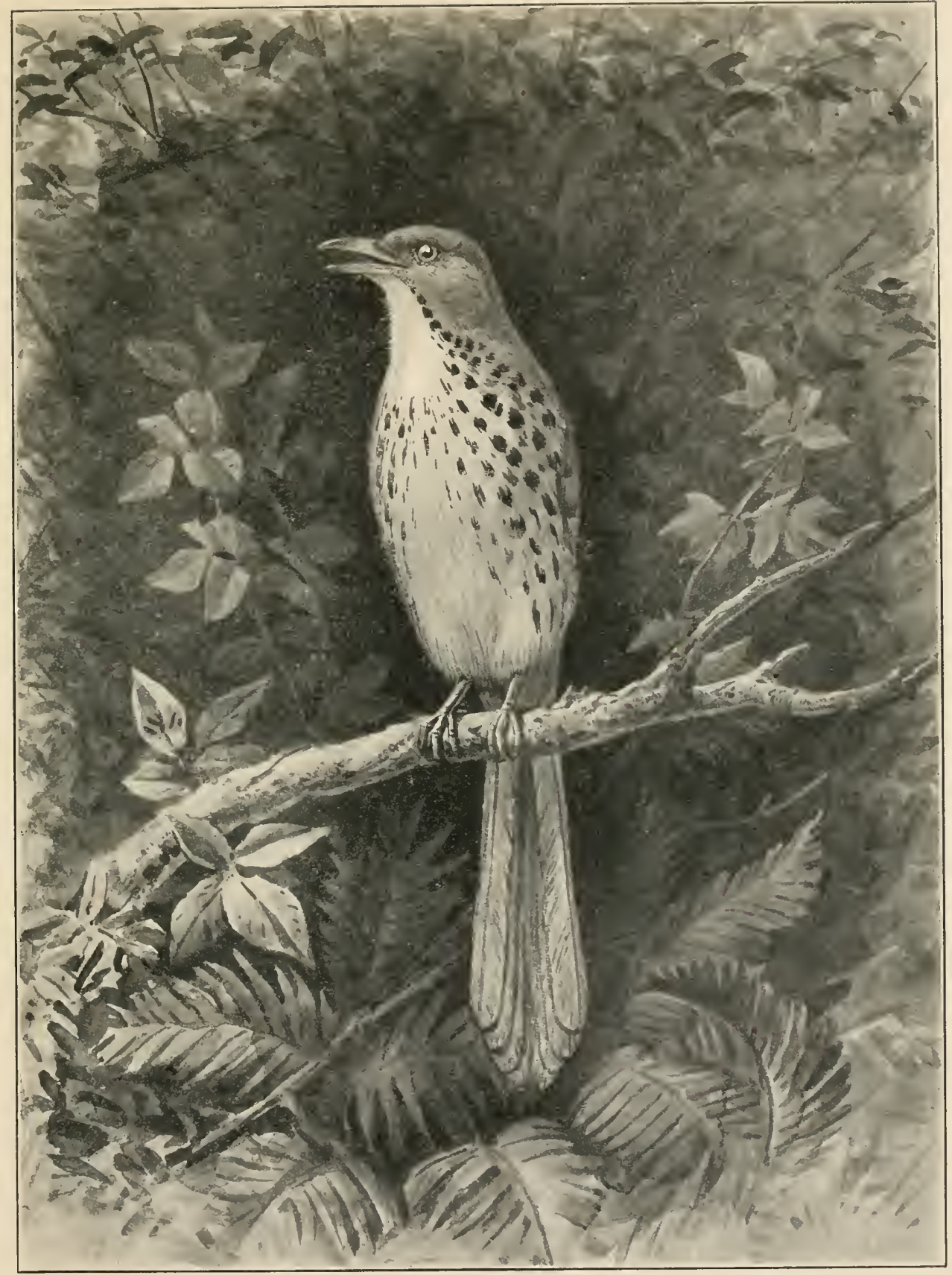

THE 'THRUSH 



\section{THE HOMING DOVE}

O WINGED messenger of love,

Of hope and peace and life in sacred lore,

Tell me, $\mathrm{O}$ silent, swift, unerring minion,

What instinct guides thy flight on downy pinion

Across the wastes of sea, the mountains o'er,

Through wind and murky storm, through night and day?

What hidden power bears thee on thy way

Safe, safe unto thy goal from foreign shore,

$\mathrm{O}$ gentle dove?

Nay, none but He who rules above

Could bear thee thus o'er sea and desert wide;

Nay, none but God could clarify thy vision,

Thou symbol of the soul for realms elysian

Bound. Naught but spirit-prescience e'er could guide

Thee true. Yea, thou a perfect symbol art

Of deathless soul, by heaven set apart-

Life's fairest emblem homing o'er death's tide-

O gentle dove! 


\section{O BIRD 'THAT CLEAVES THE AZURE SKIES}

O BIRD that cleares the azure shies

To poise the fleecy clouds among,

What glories greet your searching eyes

As to the vaulted dome you rise,

That tune your voice to thrilling song?

What visions of supernal spheres

Draw forth those melting melodies, That lilting down upon mine ears

Bring to mine eyes unbidden tears-

$\mathrm{Oh}$, tell me, whence those rhapsodies?

Oh, tell me, bird, the secret lore

That you have learned in heaven's dome;

Far, far, I watch you as you soar

The treetops and the mountains o'er-

Nay, heaven seems to be your home. 



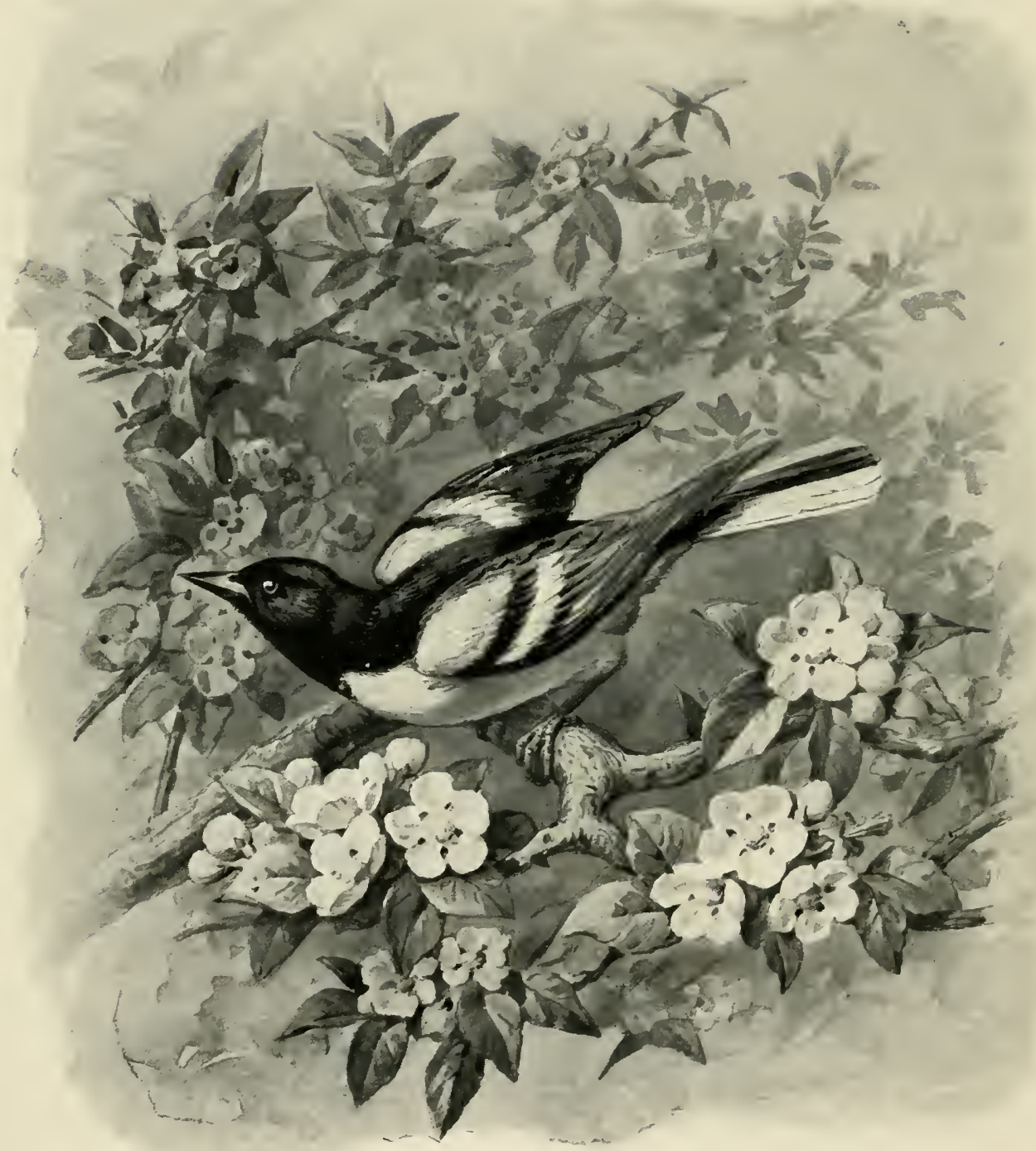

THE ORIOLE 


\section{THE ORIOLE}

A FLASH of gold and scarlet 'mid the green Of fragrant, blooming appletree, my dear

Old friend the oriole returns once more To seek his last year's nesting place, and rear His little brood again; once more to cheer My heart with his bright ways, from morn till e'en, And sing above my window as of yore.

Behold the regal songster, as he sits

Upon the swaying bough and preens his bright,

Rich plumage. Now and then his head He sidewise turns, as if he would invite The wonderment of every one in sight. Now hear him warble, as he deftly flits

From bough to bough, by wayward fancy led.

Now hear that liquid, tender, golden note; He calls his mate, a hidden place to show

Where gnarlèd branches form a perfect goal To swing their nest, secure from wanton foe; Secure from rain and mid-day's torrid glow.

There they will rear their brood, while from his throat

Will swell the song of matchless oriole. 


\section{THE SONG OF THE BOBOLINK}

WHEN the clover field is crimson and the daisies, like the snow,

O'er the pasture weave their mantle, pure and white;

When the fragrant apple blossoms to the breeze their perfume throw,

And the heart of nature's throbbing with delight;

Then the bobolink, returning from his warmer southern home, Comes again to meet the friends who've missed him long;

Comes again to spread his pinions 'neath the northern azure dome,

Comes again to greet us with his matchless song:

Bobolincon, bobolincon, ling, lang, ling;

Bobolincon, bobolincon, cling, clang, cling;

$\mathrm{Oh}$, listen to his singing, to the jubilating ringing

Of the melody he's flinging to the breezes, on the wing!

Now he rises o'er the meadow in his wanton spiral flight,

Now he pauses, all a-flutter, in mid air;

Now he swings upon a swaying plume of meadow queen, alight,

With his wings outspread to keep him balanced there.

And anon he sounds a keynote, soft and lute-like is its tone,

Low and liquid like aeolian harmony;

Now again he rises upward with a choral all his own,

With an outburst of exultant melody:

Bobolincon, bobolincon, ling, lang, ling;

Bobolincon, bobolincon, cling, clang, cling;

$\mathrm{Oh}$, listen to his singing, to the jubilating ringing

Of the melody he's flinging to the breezes, on the wing! 


\section{OH, TELL ME, YE BIRDS}

$Y_{\mathrm{E}}$ birds that to spheres empyrean belong, And cleave the vast oceans of air, Oh, tell me, why only ye revel in song, Of all God's creation so fair.

No other plumed creatures that wander abroad

In field or in fen ever pour

Forth passionate utt'rance of worship to God

Like ye, who in azure depths soar.

No creature that trails its slow progress along,

Ungifted with swift, easy flight,

E'er startles the silence with jubilant song,

Man's listening ear to delight;

None other but ye that mount ever on high,

To heaven's imperial dome,

With ravishing chorals bring dews to the eye,

And longings for heaven and home.

Ah, surely, 'tis that the good Father has bid

His angels reveal to ye birds

The glories of heaven in melodies hid,

Too pure for expression in words,

That, hearing, we also in spirit may rise

Above sordid pleasure and care,

And learn of the angels that dwell in the skies

The glories that wait for us there. 


\section{THE SEA GULL}

I GAZE afar where the stormy sea

Is merged with the sky in gloom, And ever there comes a dream to me

Of a life beyond the tomb.

As the white gull stems the winds that play

Above the foamy crest

Of the curling wave that flings its spray

Against his downy breast;

Though backward thrown again and again,

He mounts, unwearied, anew, The eddying blast 'mid the surging rain, To his haven ever true.

How like the spirit of man is he, That rises from sorrow and woe On the wings of hope o'er life's wild sea When the storm winds wildest blow!

Oh, rise, my soul, to the vaulted dome, Though trials come thick and fast, For courage and hope will bear thee home To a haven of rest at last! 



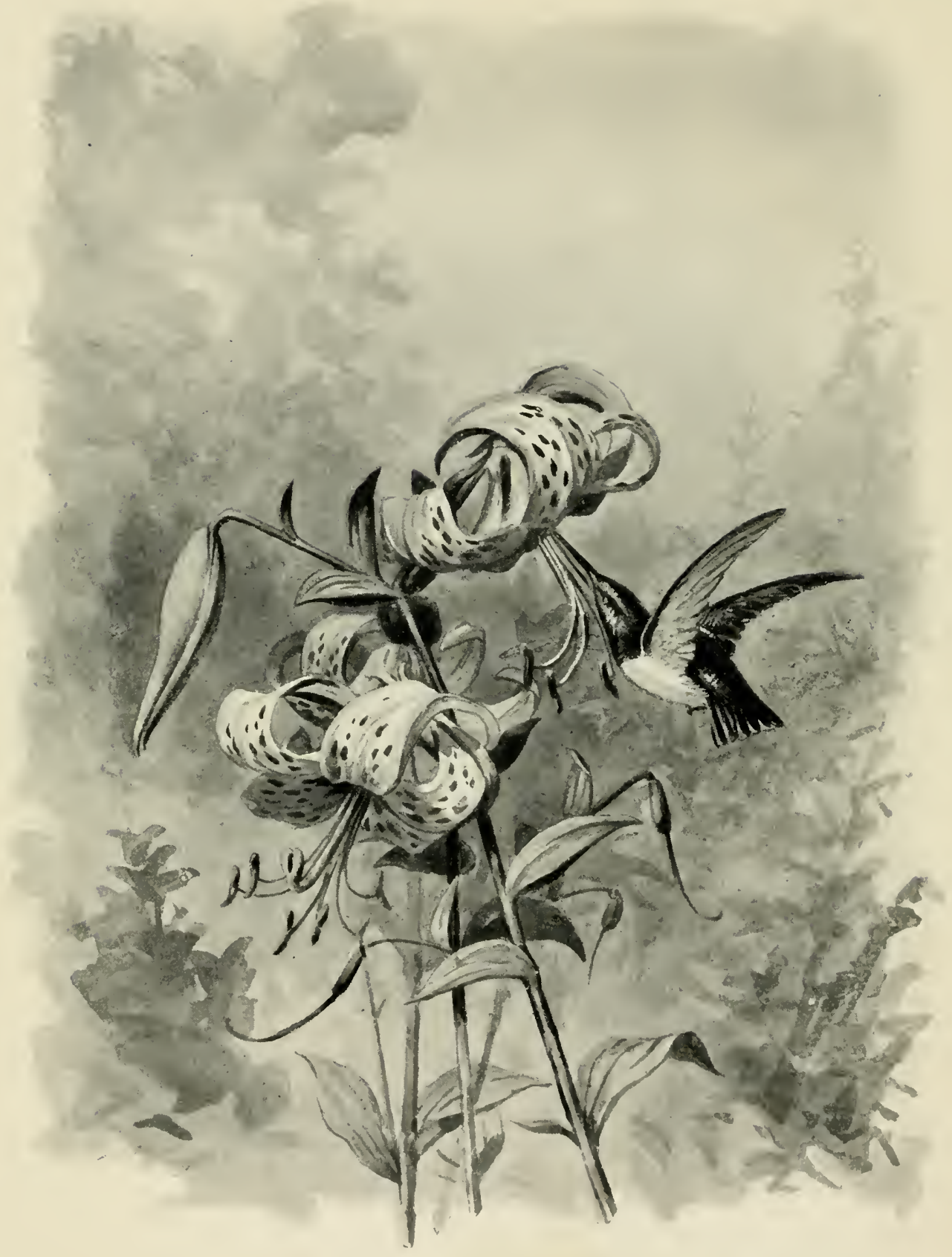

THE HLMLINAG BIRD 


\section{TO A HUMMING BIRD}

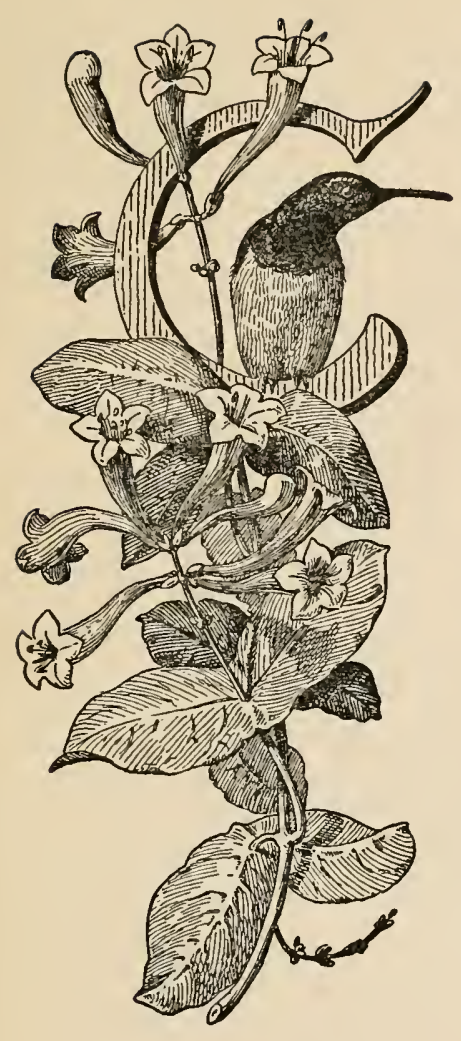

REATION rare!

O fairy bird-elusive phantom bright, Now darting through my open window, where

The drooping rose-spray scents the woodland air;

Now poising, fixt in space, a living gem

Well fit to grace a June queen's diadem;

Now, like a sentient, pulsing ray of light,

Disporting 'mong the flow'rs, too swift for sight,

To mingle there

Thy emerald with the gold, thy scarlet, pure,

With warm shade, where the lilacs hide from view

The crumbling wall-thy bronze, with purple hue

Of fragrant iris - thou, indeed, alone

The name of fairy queen of birds shouldst own!

E'er peerless shall thy magic spell endure

My wayward fancy ever to allure,

$O$ vision fair. 


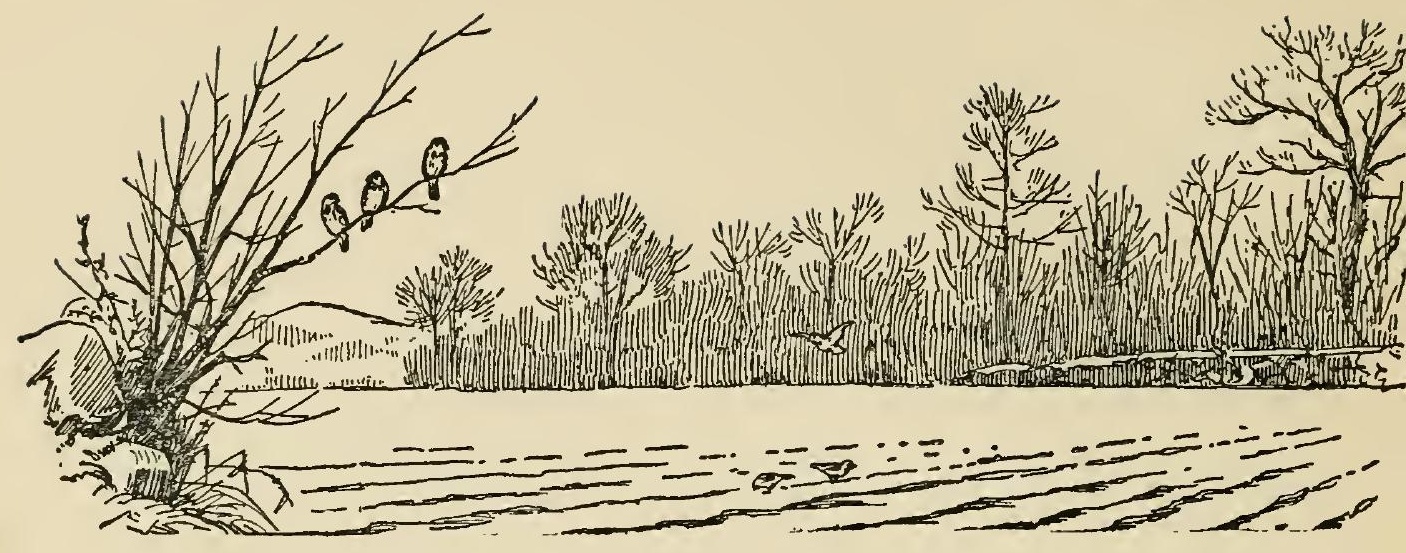

\section{THE SONG SPARROW}

W Hes lately winter's blasts are laid

And, through the crusted snow

The bare brown fields in sheltered glade

Their sodden furrows show;

When still the leafless trees resist

Fair virgin spring's caress

And but in sheltered nooks, sun-kissed,

Bold leaflets upward press,

Among the first of feathered friends

The waking earth to greet,

The bright song-sparrow early lends

His presence trim and neat.

Full bold, yet unobtrusive, he

Comes forth at peep o' day,

Exploring cranny, nook and tree

In dainty vesture gray. 


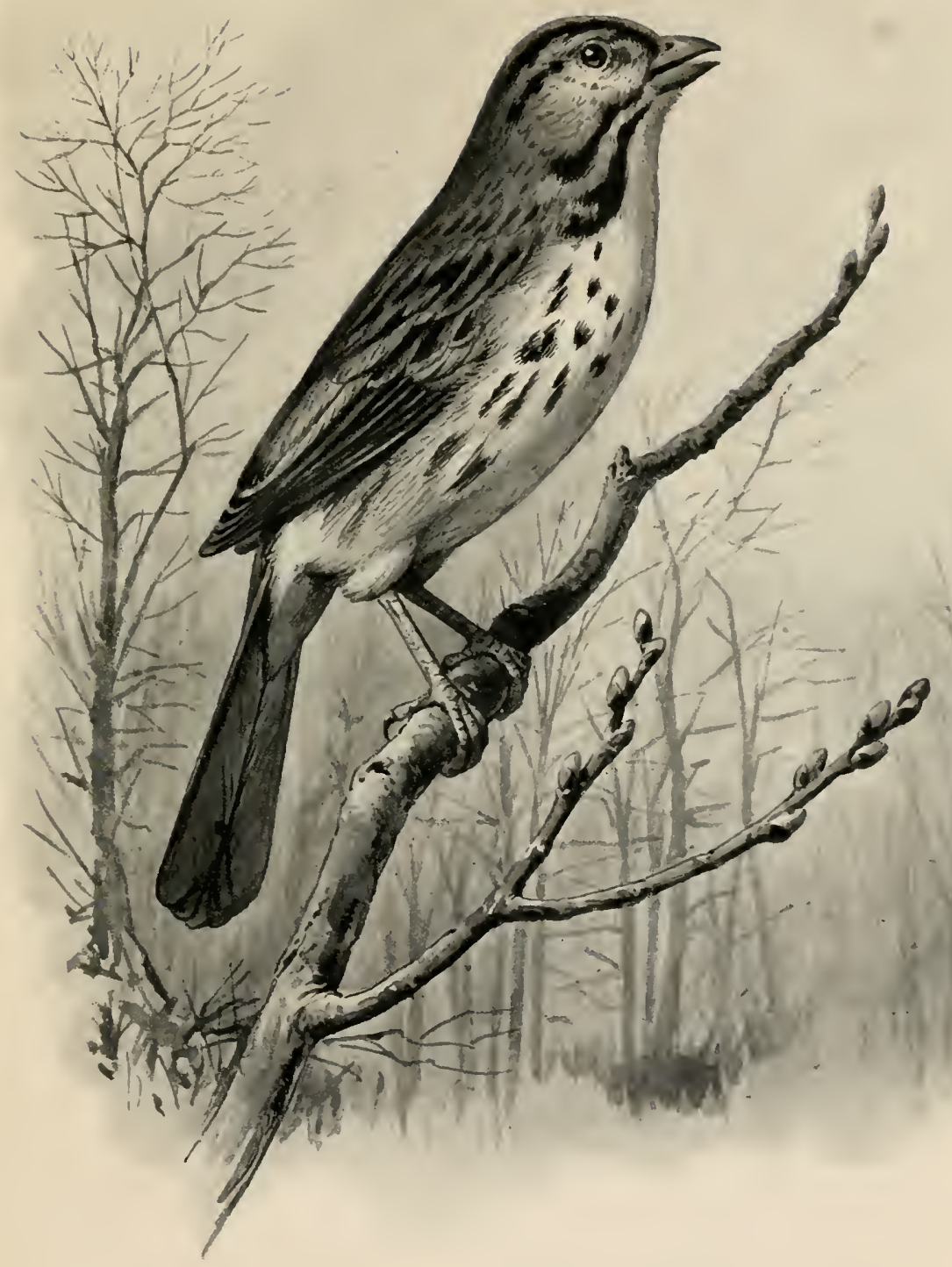

THE SONG SPARROW 

His pleasing song falls on the ear Of early passerby

With high-keyed tones, full, vibrant, clear, And wakes a glad reply

In nature's heart and, like a call

Of spring's reveille, brings

The drowsy buds to life, while all

The earth with music rings.

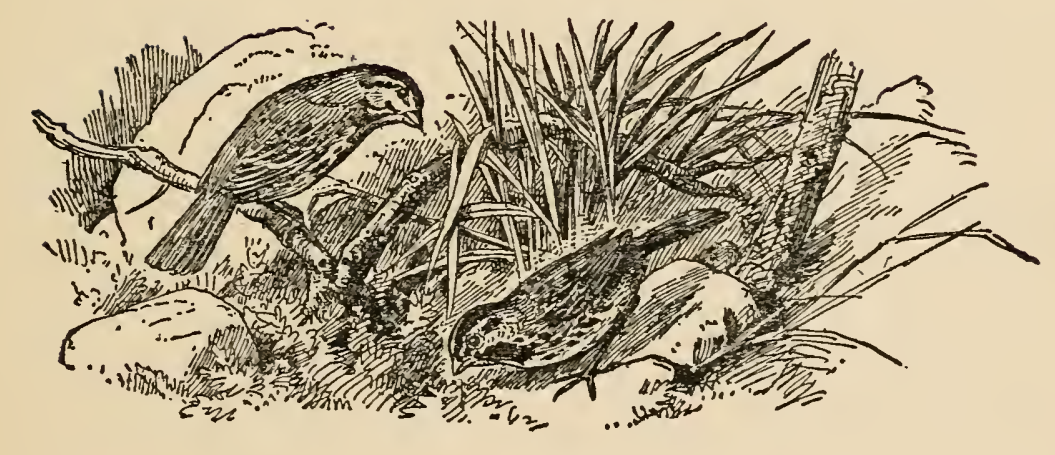




\section{THE WOUNDED BIRD}

O sTRICKEN bird, what cruel fate

Has filled with woe thy gentle breast?

What wanton fiend hath lain in wait

To tear thee from thy loving mate,

Thy helpless fledglings in the nest?

Ah, struggle not in vain to fly

And torture more thy broken wing;

Thy mute appeal for help, wellnigh, Would dim with tears a stoic's eye,

From hardest heart a sigh would wring.

Oh, couldst thou speak, what anguished tale Wouldst thou outpour in Pity's ear!

Dost think of thy dear birdlings frail

As, bleeding there, thy pulses fail

And thou beholdest death so near?

They call-Ah me, thou canst not go!

No more the shelter of thy wing And downy breast thy young may know;

No more may mother-love bestow

On them its care, nor comfort bring.

That morsel, which thou holdest still

In death, tells of thy quest for food;

Tells of thy homeward flight to fill

Those hungry mouths, nor boding ill,

'To nestle o'er thy little brood. 
Alas, alas! In vain they call,

In vain their little mouths they ope.

What black despair on thee doth fall,

As death o'erspreads thee with its pall

And dims thy last fond ray of hope!

No more wilt thou with gladsome song

Imbibe the vernal zephyr's breath,

Or wake thy young. One grievous wrong

Destruction wrought. They, too, ere long,

Like thee, will all be cold in death! 


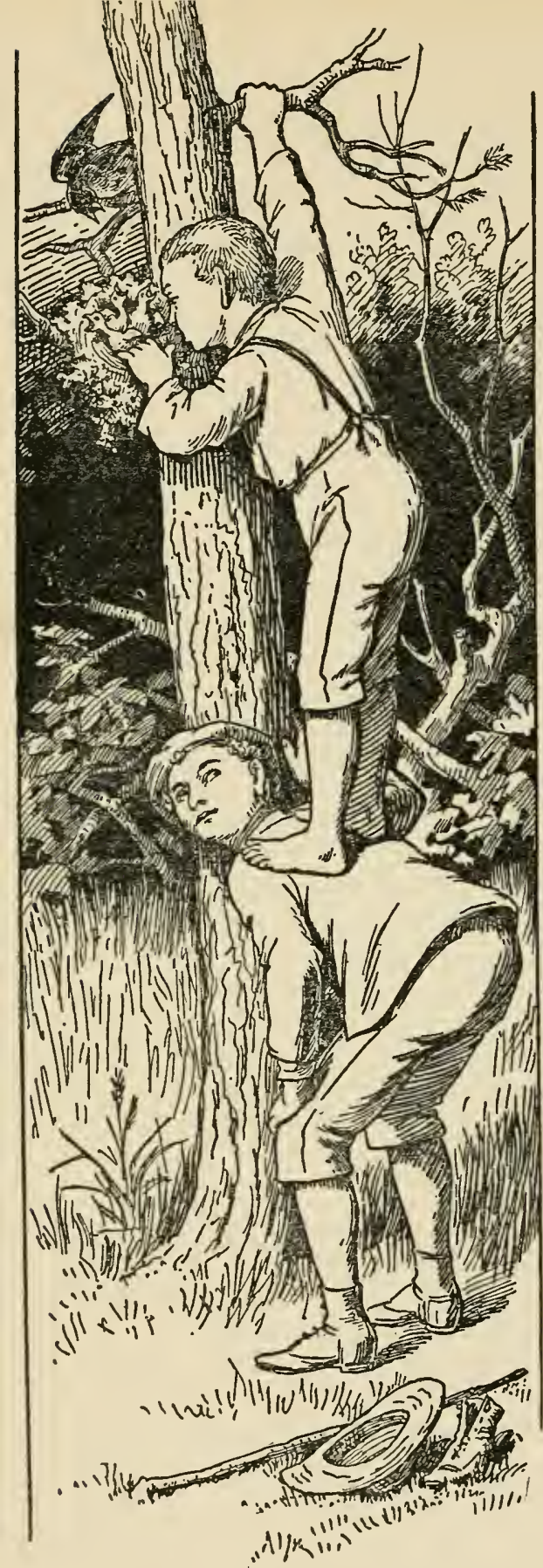

\section{THE BEREAVED ROBIN}

O PRETTY mother robin,

What makes your cry so shrill?

What makes you flit from bough to bough, This April morning chill?

Ah, gentle mother robin,

What wonder that you cry!

Your young have fallen from the nest

And cold in death they lie.

O tender mother robin,

Those young you brooded o'er

So lovingly in downy nest

Will greet you nevermore.

O stricken mother robin,

The cruel, thoughtless boy

Who robbed you of your tender brood

Has reft your life of joy.

O frantic mother robin,

What words can tell the grief

That rends your gentle mother heart

With wounds beyond relief?

$O$ childless mother robin,

My tears for you shall flow;

May God grant you forgetfulness

From all your mother's woe. 


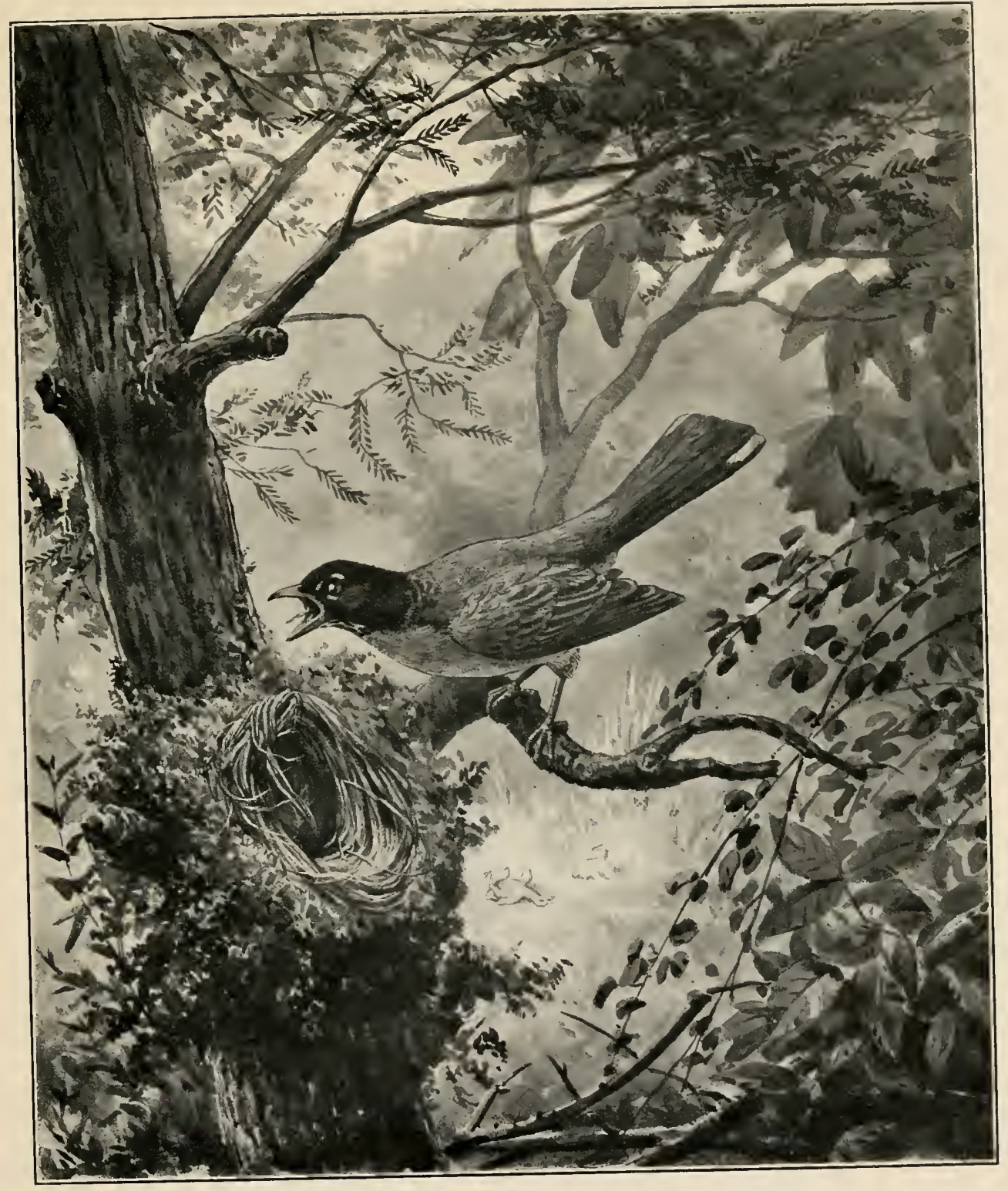

THE BEREAVED ROBIN 

Or, spare the gentle songster Whose carols in the morn

Wake us, with joyous melody, To day and hope new-born. Still not his throbbing pulses, Maim not his graceful wing; Stay not his flight beneath the skies,The bird was made to sing.

Stay, hunter, stay that missile, That messenger of death; Mar not pure heaven's harmony, Rob not its voice of breath,The voice that breaks, unbidden, Forth from a joyous heart To sing the love of nestlings dear, In nature's purest art.

Think of the wee ones waiting For mother care and love; Think of that dying agony That calls to heaven above, That calls for help and pity, Where none to help is nigh, On orphaned birdlings left alone To hunger and to die.

Oh, spare the gentle songster Whose lays at eve delight, Whose vesper anthems glorify The coming of the night; 
Still not his throbbing pulses,

Maim not his graceful wing;

Stay not his flight beneath the skies-

The bird was made to sing.

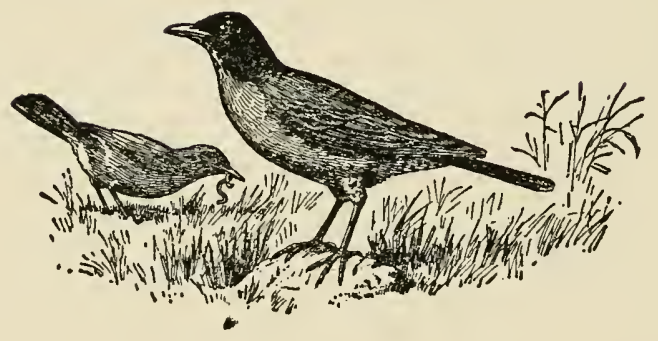

[18] 


\section{THE WHIPPOORWILL}

WHEN the earth, from slumber waking,

Thrills to gentle spring's caress, And all nature seems partaking

Of new joy and loveliness;

And the silvery moon in splendor

Mounts above the vale and hill, Flooding earth with glory tender,

Comes again the whippoorwill.

Listen, listen! Hush-be still:

"Ku-whippoorwill! Ku-whippoorwill!"

How his love-notes throb and thrill,

On the mystic silence falling,

As to distant mate he's calling:

"Whippoorwill! Ku-whippoorwill!'

Oft at eve, when gently drifting

In my quaint gondola, light,

Down the stream, and star-beams, sifting

Through the curtain of the night,

With their magic glow supernal

All the world around me fill,

Then I love to hear the vernal

Love-song of the whippoorwill.

Listen, listen! Hush-be still:

"Ku-whippoorwill! Ku-whippoorwill!"

How his love-notes throb and thrill,

On the mystic silence falling,

As to distant mate he's calling:

" 'Whippoorwill! Ku-whippoorwill!" 







COJ1213769 


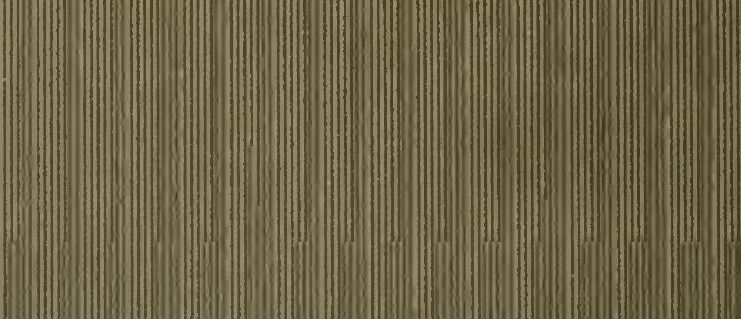

